\title{
Dziecko i dzieciństwo w średniowieczu przez pryzmat rzeczy
}

DOI: http://dx.doi.org/10.12775/LC.2017.047

\begin{abstract}
Streszczenie: Obraz dzieciństwa w okresie średniowiecza postrzegany jest przede wszystkim przez pryzmat przekazów pisanych. Nie stanowią one jednak wystarczającego źródła w tej sferze, gdyż ukazują ją jedynie z punktu widzenia osób dorosłych. Kategorią źródeł, które umożliwiają spojrzenie na wczesny okres życia oczami dziecka, są jego własne zabawki. Pokazują one, że dziecko towarzyszyło rodzicom nieustannie, zarówno podczas pracy, jak i w czasie wolnym. Pozwalało to zapewne na budowanie bliższych relacji z otoczeniem. Sam dobór zabawek okresu średniowiecza wskazuje na istnienie świadomości konieczności wszechstronnego rozwoju dziecka. Już od początku okresu wieków średnich dostarczano dziecku zabawki, które wpływały na jego rozwój we wszystkich najważniejszych aspektach: socjalizacji, rozwoju psychicznym i fizycznym, asymilacji ze społeczeństwem.
\end{abstract}

Słowa kluczowe: zabawki, dziecko, średniowiecze, wychowanie, rozwój.

\section{Child and childhood in the Middle Ages through the prism of things}

\begin{abstract}
Historical reflections on medieval childhood allow to recognize it only from the perspective of parents. We can discover more information through the analysis of medieval toys. These sources show a picture of a child who is a constant companion for adults and the people around it are its guides. The toys known from the Middle Ages prove that they were made for a specific purpose and with an intended impact on child's development. The toys affected on the most important stages of child development: socialization, mental and manual development, assimilation with the society. Adults who created toys knew that they influence on children's development and benefited from that.
\end{abstract}

Keywords: toys, child, Middle Ages, education, development.

\footnotetext{
* Absolwentka studiów doktoranckich nauk o kulturze w Instytucie Archeologii na Uniwersytecie Wrocławskim. Do jej głównych zainteresowań badawczych należą dzieciństwo oraz gry i zabawy okresu średniowiecza. E-mail: iza.gomulka@poczta.onet.pl.
} 
braz dzieciństwa w okresie średniowiecza odczytujemy przede wszystkim ze źródeł pisanych, które dostarczają w tej sferze ważnych, aczkolwiek niekompletnych informacji. Dzieci są w nich zwykle wzmiankowane jedynie przy okazji, m.in. w regulacjach prawnych i majątkowych, zapisach odnoszących się do zasad społecznych, np. w ustawach ogólnomiejskich, przekazach dotyczących działalności instytucji filantropijnych, takich jak zakony, czy też związanych z obrządkiem pogrzebowym. W późnych fazach średniowiecza coraz częściej powstają dzieła bezpośrednio dotyczące dzieci, przede wszystkim traktaty pedagogiczne, wyznaczające normy wychowawcze. Jednak wszystkie podane przykłady cechuje wspólny istotny element - subiektywny charakter zawartych w nich informacji. Bowiem wszystkie przytoczone rodzaje przekazów ukazują dziecko i dzieciństwo wyłącznie z perspektywy osób dorosłych. Źródłem pozwalającym nam na dostrzeżenie rzeczywistego świata dziecięcego, a nie tylko jego części kreowanej przez opiekunów, są przedmioty, którymi posługiwały się dzieci i które przeznaczone były specjalnie dla nich. Za najważniejszą kategorię wśród takich zabytków należy uznać zabawki dziecięce pełniące wówczas funkcję najważniejszego narzędzia poznawczego w otaczającej dzieci rzeczywistości ${ }^{1}$.

W okresie średniowiecza na terenie obecnych ziem polskich nie możemy mówić jeszcze o wyspecjalizowanej wytwórczości zabawkarskiej. Dominują wówczas zabawki tworzone przez dorosłych dla swych pociech na uboczu podstawowych gałęzi wytwórstwa. Poza tymi przedmiotami, wytworzonymi specjalnie po to, by pełniły funkcję ludyczną, zabawkami stawały się także przedmioty używane na co dzień przez dorosłych, którym funkcję zabawki nadano wtórnie. Możemy jednak mówić już w tym okresie o zróżnicowanym asortymencie przedmiotów wytwarzanych do celów zabawowych. Przyglądając się mu, można zauważyć, że zabawki nie były wówczas dobierane przypadkowo. Wyróżnić możemy trzy podstawowe grupy funkcjonalne zabawek, pod względem ich wpływu na najważniejsze zakresy rozwojowe u dzieci:

- zabawki związane z rozwojem ruchowym i manualnym dziecka,

- miniaturowe przedmioty umożliwiające socjalizację,

- instrumenty pozwalające na asymilację ze światem dorosłych.

Zabawy tego okresu wywodziły się przede wszystkim z obserwacji świata dorosłych. Do podstawowych form rozrywek dziecięcych należały zabawy ruchowe. Również ich forma wynikała często z obserwacji otoczenia, m.in. z naśladowania dorosłych przemieszczających się zimą na łyżwach. Nie dziwi w tym kontekście liczne odnajdywanie na wczesnośredniowiecznych stanowiskach okazów łyżew o tak niewielkiej długości, iż ich wykorzystanie przez dorosłych byłoby problematyczne. Różnorodne zabawy urządzane na zamarzniętych zbiornikach wodnych, z użyciem nie tylko łyżew, ale i bąków, kul czy kijów do gry, potwierdzają także późnośredniowieczne i wczesnonowożytne przedstawienia ikonograficzne, których najwięcej odnajdujemy w twórczości Pietera Bruegla Starszego. Nie można zaliczyć łyżew do typowej formy zabawki, jednakże należy podkreślić ich ówczesne wykorzystanie w zabawie. Nieco mniej popularnym przedmiotem zabawy były sanki, co wiązać możemy zapewne z większą pracochłonnością i kosztem ich wykonania, jako przedmiotów wieloele-

1 Artykuł opracowano w ramach realizowanego projektu Narodowego Centrum Nauki OPUS 4 pt. Zabawki dziecięce na ziemiach polskich do końca XIX wieku, projekt numer UMO-2012/07/B/HS3/00899. 
mentowych. Stąd też rzadziej odnajdywane są one podczas badań archeologicznych i spotykane na przedstawieniach ikonograficznych (ryc. 1).

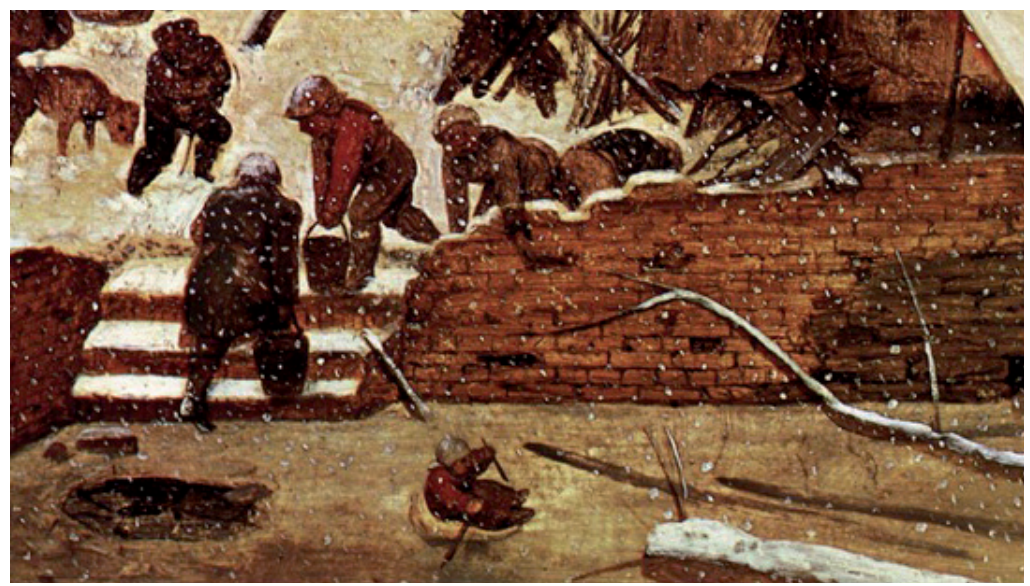

Ryc. 1. Pieter Bruegel. Wielka kolekcja stawnych malarzy. Tom 5, Poznań 2006. (wydanie albumowe bez numeracji stron).

Do powszechnych zabawek wykorzystywanych w zabawach ruchowych należały również kulki, głównie drewniane, co wynikało złatwości ich wykonania iuniwersalności.Jednak w tworzeniu zabawek tego okresu nie ograniczano się wyłącznie do najprostszych form. Popularną zabawką ruchową były również drewniane bąki. Dawały dzieciom możliwość złożonej rozrywki, wymagającej dużej zręczności. Na podstawie dotychczasowych badań na terenie obecnych ziem polskich można wyróżnić co najmniej sześć odmiennych typów bąków ${ }^{2}$, zaopatrzonych $\mathrm{w}$ dodatkowe elementy, umożliwiających różnorodne warianty zabawy (patyk, sznurek owinięty wokół szyjki, bacik do podcinania czy igła do osadzania w podłożu). W ikonografii późnośredniowiecznej bąki przedstawiane wraz z innymi zabawkami ${ }^{3}$ ukazywane są zazwyczaj w dwóch kontekstach: podczas zabaw zimowych na lodzie wraz z łyżwami i sankami oraz w zabawach na placach w towarzystwie kulek. Potwierdza to równoczesny stopień rozpowszechnienia się na terenie obecnych ziem polskich wszystkich tych rodzajów zabawek, co pokrywa się z analizą częstotliwości występowania takich znalezisk archeologicznych, pochodzących z nawarstwień datowanych ogólnie na XI-XII w.

Kolejne przytoczone rodzaje zabawek wczesnośredniowiecznych przynależą do grupy miniaturowych przedmiotów umożliwiających dzieciom socjalizację. Trzon ówczesnej edukacji dziecięcej stanowiła nauka przez naśladowanie dorosłych, przy użyciu zminiaturyzowanych przedmiotów ich pracy i innych codziennych czynności. Ważnym celem nauczania, ale i zabawy, było bowiem jak najszybsze przystosowanie dziecka do wejścia w świat dorosłych. Zabawy musiały być odzwierciedleniem codzienności dziecka, także w ramach

2 Por. Ł. Kunicka-Okuliczowa, Wczesnośredniowieczne zabawki i gry z Gdańska, [w:] Gdańsk wczesnośredniowieczny 1, red. J. Kamińska, Gdańsk 1959, s. 108-121; O. Antowska-Gorączniak, O rozrywkach poznaniaków wieków średnich. Zabawki i przedmioty do gier z Ostrowa Tumskiego, „Kronika Miasta Poznania” 2003, z. 1, s. 77-78; M. Rulewicz, Wczesnośredniowieczne zabawki i przedmioty do gier z Pomorza Zachodniego (Z badań archeologicznych prowadzonych w latach 1947-1958), "Materiały Zachodniopomorskie” 1958, t. 4, s. 306-312.

3 Do często spotykanych przedstawień należy również ukazanie dziecka bawiącego się samym bąkiem, najczęściej w pomieszczeniu w towarzystwie dorosłych wykonujących własne zajęcia. 
nauki rzemiosła, kultury stołu czy władania bronią - w chwili ich trwania jej atrybutem stawały się małe narzędzia (miniaturowe przęślice, stępory, łopatki), miniaturowa zastawa i przybory kuchenne (naczynka, łyżeczki, czerpaczki) czy drewniana broń (drewniane mieczyki lub nożyki) ${ }^{4}$. Aż do okresu przełomu gospodarczego w XIII w. do najbardziej popularnych zabawek tego typu należały okazy o uproszczonej formie i budowie jednoelementowej. W późniejszym okresie odnajdywane są częściej wyroby odzwierciedlające przedmioty bardziej zaawansowane technologicznie, stanowiące odbicie ówczesnego rozwoju rzemieślniczego. Wśród broni późnośredniowiecznej odkrywane są już okazy o bardziej złożonej formie, jak łuki czy kusze. Od XV w. wśród zabawek pojawiają się również miniaturowe naczynka wykonane z cyny i ołowiu, jednak zabytki te mają zasięg jedynie lokalny (większość znalezisk pochodzi z badań przeprowadzonych na terenie Gdańska) ${ }^{5}$.

Większa staranność wykonania przedmiotów zabawy we wczesnych fazach średniowiecza cechuje miniaturowe lódeczki z kory lub drewna ${ }^{6}$. Ten rodzaj zabawek jest grupą, której forma była w widoczny sposób zależna od przemian gospodarczych. Zaobserwować to możemy na przykładzie zabytków z terenu dorzecza Odry. Najwięcej znalezisk przypada tu na okres XI-XII w., kiedy rzeka wykorzystywana była w znacznej mierze do komunikacji między poszczególnymi ośrodkami oraz do rybołówstwa. Na ten etap przypada duża liczba okazów miniaturowych łódek będących odwzorowaniem łodzi przeznaczonych do przemieszczania się oraz połowu ryb, zachowujących nie tylko samą ich formę, ale także szczególowe funkcjonalne elementy budowy ${ }^{7}$. Od XIII w. nastąpił dynamiczny rozwój gospodarczy związany ze zwiększeniem się funkcji transportowych Odry, który postępował już od X stulecia. Przez ten czas możemy zaobserwować wśród znalezisk miniaturowych łódeczek elementy stopniowego przystosowania do funkcji transportowej, m.in. zaczepy dziobowe od XI w. - kiedy to zaczęły powstawać liczne sztuczne nabrzeża, do których cumowano takie łodzie ${ }^{8}$. Kolejnym przykładem jest częstsze stosowanie dna płaskiego, zwiększającego wyporność łodzi, co umożliwiało przewiezienie większej ilości ładunku, czy owalnej lub prosto ściętej rufy, przez co przestrzeń załadunkowa ulegała powiększeniu. Wytwórczość tego typu zabawek w późnym średniowieczu właściwie zanika.

Trzecią wspomnianą grupą zabawek są instrumenty pozwalające na asymilację dzieci ze światem dorosłych. Taniec i muzyka stanowiły nieodłączne elementy średniowiecznej rzeczywistości. Wspólne uczestnictwo wszystkich grup społecznych i wiekowych w różnego rodzaju obchodach, świętach, biesiadach było jednym z ważniejszych spoiw w funkcjonowaniu społeczności. Nie sposób wyróżnić konkretne zabytki spośród odnajdywanych podczas badań archeologicznych jako instrumenty używane przez dzieci. Jednak liczne znaleziska tego typu odkrywane pośród typowych zabawek dziecięcych oraz przykłady ikonograficzne wskazują, że przedmiotem zabaw najmłodszych były przede wszystkim in-

\footnotetext{
4 M. Rulewicz, op. cit., s. 303-351; Ł. Kunicka-Okuliczowa, op. cit., s. 107-143; O. Antowska-Gorączniak, op. cit., S. $72-85$.

5 Por. E. Trawicka, Zabytki metalowe z Wyspy Spichrzów w Gdańsku (badania z 2004 roku), „Archeologia Gdańska" 2010, t. IV, s. 93-150; Z. Polak, Zabytki metalowe, w: Archeologia średniowiecznego Kołobrzegu 2, red. M. Rębkowski, Kołobrzeg 1997, s. 173-181.

6 P. Smolarek, Studia nad szkutnictwem Pomorza Gdańskiego X-XIII wieku, Gdańsk 1967.

7 Zob. S. Moździoch, Znaczenie „pożytków wodnych” w życiu codziennym mieszkańców wczesnośredniowiecznego Śląska, [w:] Rzeki: kultura - cywilizacja - historia 2, red. J. Kułtuniak, Katowice 1993, s. 149-169; I. Gomułka, Zabawa odbiciem rzeczywistości - łódki zabawki z Gdańska i Opola jako odzwierciedlenie lokalnego szkutnictwa średniowiecznego, [w:] Życie codzienne przez pryzmat rzeczy, red. P. Kucypera, S. Wadyl, Toruń 2010, s. 321-331.

8 S. Moździoch, op. cit., s.152-154.
} 
strumenty o uproszczonej budowie, niewymagające większych umiejętności od osoby grającej. Zakres takich przedmiotów jest dosyć szeroki - od prostych świstawek i piszczałek, przez fujarki, gwizdki, hetki, do bardziej złożonych, jak flety i dzwoneczki. Niektóre z nich pełniły również inne poza muzyczną funkcje, niezwiązane ze sferą ludyczną. Należy wymienić tu przede wszystkim grzechotki, prawdopodobnie pierwszy instrument w rękach dziecka. Przedmiot ten powszechnie we wczesnych fazach średniowiecza łączono z obrzędowością. Porównanie znalezisk znanych z terenu ziem polskich dowodzi, że funkcję tę wiązać możemy przede wszystkim z okazami o dużej staranności i pracochłonności wykonania, tworzonymi z użyciem dodatkowych technik zdobniczych, m.in. różnobarwnych polew. W przeciwieństwie do takich okazów, odnajdowanych z podobną częstotliwością na cmentarzyskach i stanowiskach osadniczych, wyróżniają się zabytki znane głównie z osad, które charakteryzują prosta technika wykonania, a także uproszczone formy, bądź takie nawiązujące bezpośrednio do przedmiotów codziennego użytku, głównie naczyń. Tego typu znaleziska możemy prawdopodobnie wiązać z funkcją ludyczną, tym bardziej że wiele z nich odnaleziono pośród innych zabawek ${ }^{9}$. Problem wielofunkcyjności dotyczy również licznie odnajdywanych podczas badań hetek kościanych, z których część pełniła funkcję aerofonów wirujących. Wykonywano je często jedynie przez nawiercenie otworu w kości śródręcza lub śródstopia świni. Łatwość wykonania oraz powszechna dostępność surowca sprawiały, że wykorzystywano je na różnorodne sposoby, m.in. jako guziki, taka funkcja przypisywana jest szczególnie okazom o dwóch otworach czy ściętych nasadach kości, co nie ma praktycznego zastosowania w przypadku instrumentów. W późnych fazach średniowiecza asortyment instrumentów odnajdywanych podczas badań pośród zabawek dziecięcych poszerza się o drumle.

$\mathrm{Na}$ terenie obecnych ziem polskich wiek XIII przyniósł wyraźne przemiany również w wytwórczości zabawkarskiej. Wśród znalezisk późnośredniowiecznych nadal obecne są omówione wcześniej rodzaje zabawek, jednak we wszystkich przypadkach wyraźnie widać słabnięcie ich popularności. Ówczesne przyspieszenie rozwoju gospodarczego wiązało się z rozszerzeniem stosowanych surowców produkcyjnych. Miejsce dominujących we wczesnym średniowieczu zabawek drewnianych zajmują okazy wykonane z gliny. Wśród kulek przeważają znaleziska gliniane i kamienne, spotykane są również coraz częściej kuleczki szklane. Jednak należy podkreślić, że znaczną część kulek wykorzystywano do celów niezwiązanych z zabawą, np. jako pociski do broni palnej czy procy. Kulki wykonywane z gliny czy kamienia zaczynają być wytwarzane na terenie obecnych ziem polskich w dużych ilościach i odnajdywane w całych zespołach od schyłku średniowiecza. W XV w. odnotowano również wzrost występowania kulek drewnianych, przeważających w nawarstwieniach wczesnośredniowiecznych, zaś o wiele rzadziej odkrywanych w nawarstwieniach datowanych na późne fazy wieków średnich. Zjawisko to wiązać należy z upowszechnieniem się $\mathrm{w}$ tym okresie różnego typu kijów do gier, w których wykorzystywano również drewniane kule. Pojawiają się wówczas także skórzane piłki. Z terenu dorzecza Odry znane są trzy okazy: dwie z Wrocławia (plac Nowy Targ) oraz z Bytomia ${ }^{10}$, są to piłki wykonane z przeplatanych pasków skórzanych. Drugi typ piłek, zszywanych z trzech elementów: dwóch kół i po-

9 Przykładem mogą być znaleziska odkryte podczas badań placu Nowy Targ we Wrocławiu (I. Gomułka, w druku).

10 Skarby ziemi wydarte: Górny Śląsk i pogranicze, red. E. Tomczak, Katowice 2005, s. 122-123. 
dłużnego paska, odnaleziono w Elblągu ${ }^{11}$ (okaz ten pochodzi z XV w.) oraz w Kołobrzegu ${ }^{12}$ (datowany na XIV w.). Najstarszy odnaleziony dotąd na ziemiach polskich okaz pochodzi z Gdańska z badań Wyspy Spichrzów i datowany jest na XIII/XIV w. ${ }^{13}$

Wraz z rozwojem miast i ich przestrzeni publicznej wzrasta także liczba elementów różnego rodzaju gier zręcznościowych i planszowych, jednak nie wszystkie z nich przeznaczone były dla dzieci. Wśród okazów używanych w zabawie przez dzieci wymienić można astragale i człony placowe wykorzystywane jako kości do gry. W zabawie pełniły funkcję podobną do kostek sześciennych, dzięki oznakowaniu ścianek, dając tym samym większe możliwości wprowadzenia formy punktacji. Kości palców stosowano m.in. w grze, w której ustawiano je w szereg i rzucano w nie kulami, na wzór kręgli.

Zmiana preferencji surowcowych jest wyraźnie widoczna w przypadku figurek zwierzęcych. We wczesnym średniowieczu dzieci bawiły się drewnianymi wyobrażeniami zwierząt, które znały ze swego otoczenia, takimi jak ptaki, psy, konie. Przedmiotem ich zabaw były również figurki znanych im zwierząt dzikich: jeleni, lisów, zajęcy, niedźwiedzi. Figurki takie wykonywano głównie z drewna, również z kory, rogu i poroża. Natomiast $\mathrm{w}$ formach późnośredniowiecznych figurek zwierzęcych znalazły odbicie przede wszystkim rozwój rzemieślnictwa oraz kształtowanie się rycerstwa. Dominującym typem znalezisk stały się gliniane figurki koników i jeźdźców-rycerzy. Wyróżniają się one starannym wykonaniem i szczegółową formą, a przede wszystkim stosowaniem metody pokrywania wyrobów glazurą. Zmiany te są wynikiem rozwoju handlu dalekosiężnego i silnych kontaktów z niemieckimi centrami wytwórczymi, które uważane są za głównych wytwórców glinianej drobnej plastyki figuralnej ${ }^{14}$.

Zabawką bezpośrednio odnoszącą się do wychowywania była lalka, zwana wówczas łątką. Zwykle nadawano im bardzo prostą formę, często jedynie dwuelementową z zaznaczeniem głowy. Lalki te wykonywano z najprostszych do zdobycia i obróbki materiałów, często były to zapewne zwykłe patyki przybrane fragmentami tkanin. Stąd też wynika ich bardzo niska rozpoznawalność w materiałach archeologicznych. Twórcy lalek zwykle nie zaznaczali nóg albo rąk, jak również strojów ani elementów, które mogłyby je imitować. Dopiero od końca XIII w. znane są z badań Elbląga bardziej złożone egzemplarze, które prawdopodobnie mogły być zaopatrzone w ruchome kończyny. Do rozwoju lalki w późnych fazach średniowiecza przyczynił się Kościól, który w ramach przybliżenia ludowi religii organizował opowiadające o niej teatrzyki lalkowe. Od XIV w. mamy już prawdopodobnie do czynienia z lalkami - kukiełkami teatralnymi. Okazy takie odkryto na terenie Elbląga ${ }^{15}$. Jednak formy najprostsze były popularne zapewne przez cały okres średniowie-

\footnotetext{
11 M. Marcinkowski, Stan badań nad średniowiecznymi przedmiotami ze skóry odkrytymi w Elblagu, [w:] Studia nad średniowiecznym skórnictwem, red. A. B. Kowalska, Szczecin 2009, s. 192; A. Stempin, Magia gry - sztuka rywalizacji, Poznań 2012, s. 95.

12 Archeologia średniowiecznego Kołobrzegu, t. 5, red. M. Rębkowski, Kołobrzeg 2010.

13 Zabytek znajduje się w zbiorach Muzeum Archeologicznego w Gdańsku.

14 T. Borkowski, Rozrywka - zabawki i drobna plastyka figuralna, [w:] Ze studiów nad życiem codziennym w średniowiecznym mieście: parcele przy ulicy Więziennej 10-11 we Wrocławiu, red. C. Buśko, J. Piekalski, Wrocław 1999, s. 187-201; idem, Produkcja figurek ceramicznych w późnośredniowiecznym Wrocławiu, [w:] Wrocław na przełomie średniowiecza i czasów nowożytnych. Materialne przejawy życia codziennego, red. J. Piekalski, K. Wachowski, Wrocław 2004, s. 207-209, 214; I. Gomułka, Produkcja figurek glinianych koników na terenie Śląska, „Śląskie Sprawozdania Archeologiczne" 2015, t. 56, s. 261-282.

15 G. Nawrolska, Uwagi o średniowiecznym rzemiośle elbląskim, „Elbląskie Studia Muzealne” 2009, nr 1, s. 87-105; eadem, Children and Their Childhood in Medieval Elbląg, [w:] Lübecker Kolloquium zur Stadtarchäologie
} 
cza. Z tym rodzajem zabawki wiązać można również pojedyncze znaleziska miniaturowych wózków (jedyny okaz w całości odnaleziono na Ostrówku w Opolu) ${ }^{16}$ lub częściej tylko ich elementów (kółka, osie). Takie miniaturowe wózeczki mogły być wykorzystywane do wożenia lalek lub innych zabawek, jak również dzieci mogły się nimi wozić nawzajem.

Jedną z najłatwiej dostępnych zabawek był kijek, patyk czy drewniany drąg. Jego różne formy i rozmiary stwarzały wiele możliwości zabawy. Niestety zabawki te zapewne bardzo łatwo ulegały uszkodzeniom, przez co znamy jedynie kilka zachowanych okazów. Należą do nich m.in. szczudło odkryte we Wrocławiu przy ulicy Marii Magdaleny ${ }^{17}$, a także kije do gry $\mathrm{z}$ Bytomia ${ }^{18}$ oraz Elbląga czy odnaleziona również tam drewniana głowa konia do osadzeniu na kiju ${ }^{19}$. Kije służyły m.in. do gier kulami wykonanymi z różnych surowców, co potwierdza ikonografia, a także znalezisko kija z Bytomia, odkrytego wraz z kulami drewnianymi. W przeciwieństwie do odkryć archeologicznych ikonografia prezentuje ogromną popularność tego typu zabawek, która znacząco wzrasta u schyłku średniowiecza. Najczęściej ukazywanym motywem było dziecko bawiące się na kijku wyobrażającym konia (ryc. 2). Zazwyczaj w drugiej ręce trzymało wiatraczek lub kijek, który służył mu za bat do popędzania zwierzęcia. Często ukazywano również zabawy z użyciem serso, którego funkcję mogły pełnić np. obręcz od beczki czy zepsute koło od wozu.

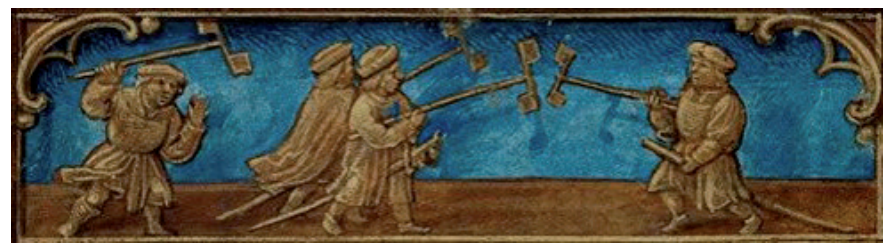

Ryc. 2 Czerwiec (fragment), Book of hours, The Golf Book, 1520-1530; źródło: W. Endrei, Spiele und Unterhaltung im alten Europa, Hanau 1988, il. IX; http://www.bl.uk/onlinegallery/ttp/golf/accessible (dostęp: 01.02.2017).

Świat dziecka kreowany był przez otoczenie, w którym funkcjonowało i do którego próbowało się dostosować w procesie asymilacji kulturowej, w dużym stopniu opartym na kulturze materialnej. Najsilniej bowiem w tym właśnie okresie dziejów zabawki odzwierciedlały rzeczywistość, która otaczała najmłodszych. Badanie zmienności form zabawek i ich popularności w poszczególnych wiekach okresu średniowiecza (ryc. 3) wskazało na funkcjonowanie podstawowej myśli pedagogicznej w wychowaniu dziecka.

im Hanseraum VIII. Kindheit und Jugend, Ausbildung und Freizeit, red. M. Gläser, Lubeka 2012, s. 310-311; I. Gomułka, Drewniane średniowieczne lalki z badań archeologicznych, [w:] Dawne i współczesne zabawki dziecięce, red. D. Żołądź-Strzelczyk, K. Kabacińska, Poznań 2010.

16 J. Bukowska-Gedigowa, B. Gediga, Wczesnośredniowieczny gród na Ostrówku w Opolu, Wrocław-WarszawaKraków-Gdańsk-Łódź 1986, s. 56; W. Hołubowicz, Z prac wykopaliskowych na Ostrówku w Opolu w roku 1956, "Sprawozdania Archeologiczne" 1959, t. 6, s. 127.

17 T. Borkowski, Gliniane skarbonki, przybory do gier, figurki ceramiczne oraz szczudło i flet z badań we Wrocławiu, [w:] Wrocław na przełomie średniowiecza i czasów nowożytnych, s. 274-275.

18 Skarby ziemi wydarte: Górny Śląsk i pogranicze, s. 122.

19 M. Marcinkowski, Zabawki dzieci elbląskich. Prezentacja zbioru z badań wykopaliskowych, [w:] Dawne i współczesne zabawki dziecięce. 


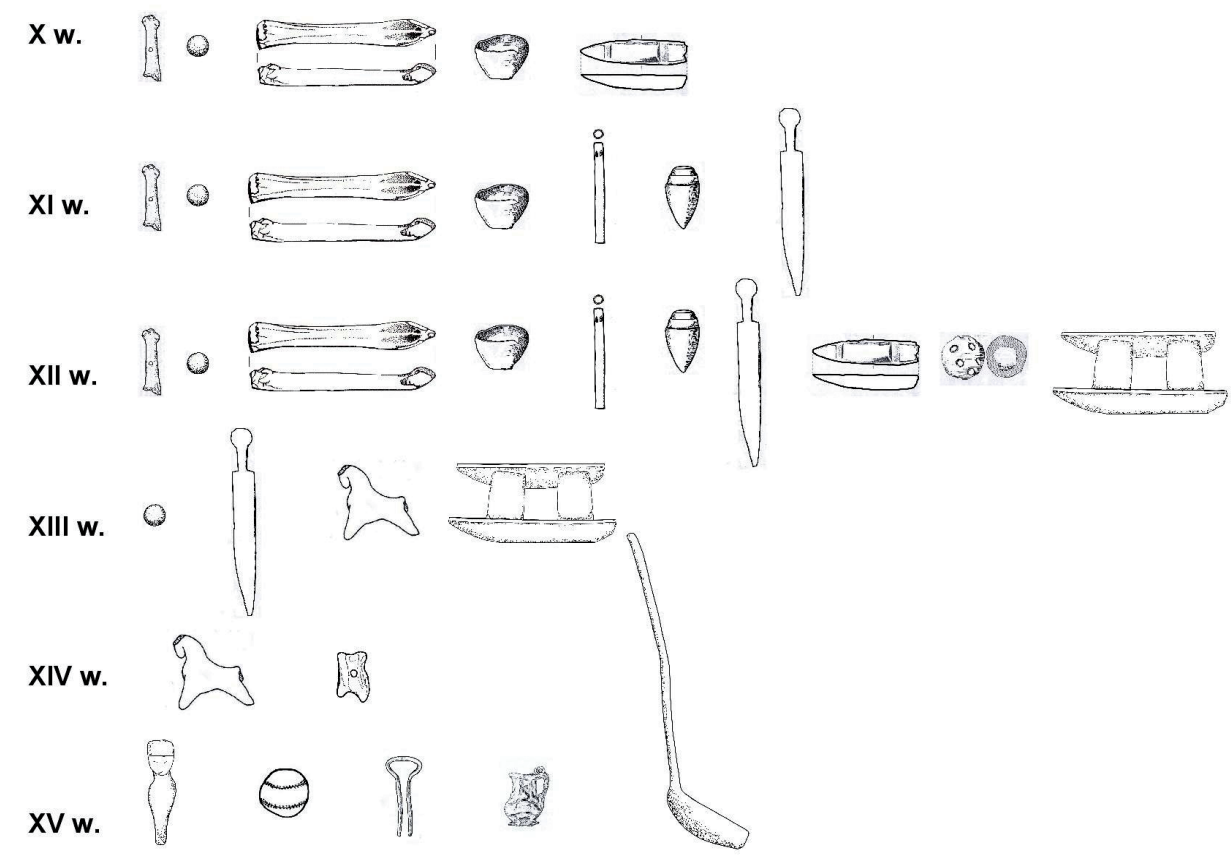

Ryc. 3 Wykaz najpopularniejszych typów zabawek w poszczególnych wiekach okresu średniowiecza; oprac. I. Gomułka.

Kluczem do tej tezy jest zaobserwowany celowy dobór zabawek, podyktowany zapewne troską o odpowiedni rozwój dzieci. Już od początku wieków średnich dostarczano dzieciom zabawki wpływające na jego rozwój we wszystkich najważniejszych aspektach: socjalizacji, rozwoju psychicznym i fizycznym oraz asymilacji społecznej. W późnych fazach średniowiecza widoczna jest natomiast tendencja do ulepszania wyrobów zabawkowych, wprowadzania bardziej wymagających w wytwarzaniu zabawek wieloelementowych, stosowania nowych rozwiązań technologicznych, nawet zapożyczeń. Możemy odczytywać to jako oznakę świadomości ważnej roli zabawek, a także uczuciowego stosunku dorosłych do dzieci, którzy próbowali w ramach swoich możliwości zaspokajać ich potrzeby.

Na podstawie przytoczonych danych możemy również spojrzeć na ówczesną rzeczywistość z perspektywy dzieci. Uzyskujemy wówczas obraz dziecka, które nie tylko ma za zadanie jak najszybciej nabyć kompetencji niezbędne do funkcjonowania w społeczności. Niewątpliwie ważnym elementem były zabawy, które prowadziły do nauki i poznawania otaczającego świata, jednak nie mniej istotne pozostawały również zabawy ruchowe. Dawały możliwość wspólnej rozrywki dzieci i dorosłych, przede wszystkim w postaci gier zespołowych, takich jak piłki, kije i kości do gry. Od najmłodszych lat dzieciom towarzyszyła również muzyka, od grzechotek po instrumenty wykorzystywane w zabawach tanecznych. Badanie zabawek dziecięcych tego okresu ukazuje ówczesne dzieci jako nieustannych towarzyszy dorosłych. Podczas wykonywania pracy najmłodsi podpatrywali swoich opiekunów, próbując nauczyć się używania narzędzi pracy w specjalnie dla nich zminiaturyzowanej wersji. Podobnie asystowały rodzicom podczas zajęć domowych. Co jest chyba nawet ważniejsze, dorośli i dzieci spędzali wspólnie także czas wolny, m.in. podczas gier i zabaw 
tanecznych. Taki sposób wychowania pozwalał na budowanie silnych więzi społecznych i choć w okresie średniowiecza dziecko było powszechnie traktowane jako niepełnoprawny członek społeczeństwa, to zapewne aktywnie uczestnicząc w jego życiu, mogło czuć się jego ważną częścią.

\section{Bibliografia}

Antowska-Gorączniak Olga, O rozrywkach poznaniaków wieków średnich. Zabawki i przedmioty do gier z Ostrowa Tumskiego, „Kronika Miasta Poznania” 2003, z. 1.

Borkowski Tomasz, Rozrywka - zabawki i drobna plastyka figuralna, [w: Ze studiów nad życiem codziennym w średniowiecznym mieście: parcele przy ulicy Więziennej 10-11 we Wroctawiu, red. Cezary Buśko, Jerzy Piekalski, Wrocław: GAJT, 1999.

-, Gliniane skarbonki, przybory do gier, figurki ceramiczne oraz szczudto i flet z badań we Wroctawiu, [w:] Wroctaw na przetomie średniowiecza i czasów nowożytnych. Materialne przejawy życia codziennego, red. Jerzy Piekalski, Krzysztof Wachowski, Wrocław: Uniwersytet Wrocławski, 2004.

—, Produkcja figurek ceramicznych w późnośredniowiecznym Wrocławiu, [w:] Wroctaw na przełomie średniowiecza i czasów nowożytnych. Materialne przejawy życia codziennego, red. Jerzy Piekalski, Krzysztof Wachowski, Wrocław: Uniwersytet Wrocławski, 2004.

Blaževičius Povilas, Seniausieji Lietuvos žaislai, Nacionalinis Muziejus Lietuvos Didțiosos Kunigaikdtystës valdovř rümai, Vilnius: Spausdino UAB „Baltoprint“ 2011.

Buchholz Rita, Mittelalterlich frühzeitliche Spielzeugfunde aus Wismar, Wismarer Studien zur Archäologie und Geschichte 1, Wismar: Stadtgeschichtliches Museum 1990.

Bukowska-Gedigowa Janina, Gediga Bogusław, Wczesnośredniowieczny gród na Ostrówku w Opolu, Wrocław-Warszawa-Kraków-Gdańsk-Łódź: Zakład Narodowy im. Ossolińskich, 1986.

Endrei Walter, Spiele und Unterhaltung im alten Europa, Hanau: Dausien, 1988.

Gomułka Izabela, Zabawa odbiciem rzeczywistości - łódki zabawki z Gdańska i Opola jako odzwierciedlenie lokalnego szkutnictwa średniowiecznego, [w:] Życie codzienne przez pryzmat rzeczy, red. Paweł Kucypera, Sławomir Wadyl, Toruń: Wydawnictwo Naukowe Uniwersytetu Mikołaja Kopernika, 2010.

—, Drewniane średniowieczne lalki z badań archeologicznych, [w:] Dawne i współczesne zabawki dziecięce, red. Dorota Żolądź-Strzelczyk, Katarzyna Kabacińska, Poznań: Wydawnictwo Rys, 2010.

—, Produkcja figurek glinianych koników na terenie Ślaska, „Śląskie Sprawozdania Archeologiczne” 2015, t. 56.

Jaworski Krzysztof, Wyroby z kości i poroża w kulturze wczesnośredniowiecznego Ostrowa Tumskiego we Wroctawiu, Wrocław: Volumen, Uniwersytet Wrocławski, 1990.

Hołubowicz Włodzimierz, Z prac wykopaliskowych na Ostrówku w Opolu w roku 1956, „Sprawozdania Archeologiczne" 1959, t. 6.

Archeologia średniowiecznego Kotobrzegu, t. 5, red. Marian Rębkowski, Kołobrzeg: Instytut Archeologii i Etnologii Polskiej Akademii Nauk, 2010.

Kunicka-Okuliczowa Łucja, Wczesnośredniowieczne zabawki igry z Gdańska, [w:] Gdańsk wczesnośredniowieczny 1, red. Janina Kamińska, Gdańsk: GTN, 1959.

Marcinkowski Mirosław, Stan badań nad średniowiecznymi przedmiotami ze skóry odkrytymi $w$ Elblagu, [w: ] Studia nad średniowiecznym skórnictwem, red. Anna B. Kowalska, Szczecin: Wydawnictwo Instytutu Archeologii i Etnologii PAN, 2009. 
—, Zabawki dzieci elbląkich. Prezentacja zbioru z badań wykopaliskowych, [w:] Dawne i wspótczesne zabawki dziecięce, red. Dorota Żołądź-Strzelczyk, Katarzyna Kabacińska, Poznań: Wydawnictwo Rys, 2010.

Moździoch Sławomir, Znaczenie „pożytków wodnych” w życiu codziennym mieszkańców wczesnośredniowiecznego Ślaska, [w:] Rzeki: kultura - cywilizacja - historia 2, red. Jerzy Kultuniak, Katowice: Muzeum Śląskie, 1993.

Nawrolska Grażyna, Uwagi o średniowiecznym rzemiośle elbląskim, „Elbląskie Studia Muzealne” 2009, $\mathrm{nr} 1$.

-, Children and Their Childhood in Medieval Elblag, [w:] Lübecker Kolloquium zur Stadtarchäologie im Hanseraum VIII, red. Manfred Gläser, Lubeka, 2012.

Polak Zbigniew, Zabytki metalowe, w: Archeologia średniowiecznego Kołobrzegu, t. 2, red. Marian Rębkowski, Kołobrzeg: Instytut Archeologii i Etnologii Polskiej Akademii Nauk, 1997.

Rulewicz Marian, Wczesnośredniowieczne zabawki i przedmioty do gier z Pomorza Zachodniego ( $\mathrm{Z}$ badań archeologicznych prowadzonych w latach 1947-1958), „Materiały Zachodniopomorskie” 1958 , t. 4.

Smolarek Przemysław, Studia nad szkutnictwem Pomorza Gdańskiego X-XIII wieku, Gdańsk: Wydawnictwo Morskie, 1969.

Stempin Agnieszka, Magia gry - sztuka rywalizacji, Poznań: Muzeum Archeologiczne, 2012.

Steiger Eva, Steiger Ivan, Umèní hraček dvou tisíciletí, Obrázkový průvodce zlatým věkem historických hraček, Praha: Muzeum hraček, 2013.

Skarby ziemi wydarte: Górny Ślask i pogranicze, red. Eugeniusz Tomczak, Katowice: Śląskie Centrum Dziedzictwa Kulturowego, 2005.

Trawicka Ewa, Zabytki metalowe z Wyspy Spichrzów w Gdańsku (badania z 2004 roku), „Archeologia Gdańska” 2010, t. IV.

Wywrot Beata, Wyroby skórzane, w: Archeologia średniowiecznego Kołobrzegu 1, red. Marian Rębkowski, Kołobrzeg: Instytut Archeologii i Etnologii Polskiej Akademii Nauk, 1996.

Wywrot-Wyszkowska Beata, Późnośredniowieczne zabytki skórzane - problemy badawcze i możliwości interpretacyjne, [w:] Studia na średniowiecznym skórnictwem, red. Anna B. Kowalska, Szczecin: Wydawnictwo Instytutu Archeologii i Etnologii PAN, 2009.

Végh János, Malarstwo niderlandzkie XV wieku, Warszawa: Wydawnictwa Artystyczne i Filmowe, 1979. 